\title{
Immune Presence
}

National Cancer Institute

\section{Source}

National Cancer Institute. Immune Presence. NCI Thesaurus. Code C159476.

Describes the percent of a tissue's surface area occupied by immune cell infiltration. 